\title{
As várias faces da Igreja Católica
}

\author{
LUIZ ALBERTO GÓMEZ DE SOUZA
}

$\mathrm{N}$ Ão É FÁCIL escrever sobre uma instituição tão complexa e heterogênea como a Igreja Católica, com suas divisões e tensões internas. Para Émile Poulat é um típico caso de conflito no consenso ou de consenso no conflito $^{1}$. Nela se cruzam diferentes tendências que têm a ver com a diversidade social, política, cultural e claro está, espiritual da sociedade mais ampla onde ela se insere. Assim, alguém que faz parte de uma pastoral comprometida com lutas sociais, como a Comissão da Pastoral da Terra (CPT) tem uma prática e opções diferentes de um membro de Opus Dei. Mas além disso, temos de distinguir entre a Igreja Católica como instituição, com suas estruturas de poder eclesiástico e como comunidade de fiéis, ou povo de Deus, para empregar uma expressão do Concílio Vaticano II. No caso brasileiro, é bom levar em conta ainda, a Igreja é um ator importante na vida social, política e cultural do país. Indicarei as linhas dessa presença, tratando de não simplificar ou idealizar, fazendo notar tensões e diferenças internas.

Antes de mais nada, alguns dados quantitativos, sem esquecer os limites dos mesmos. De censo a censo, diminui a proporção dos que se declaram católicos, ainda que cresçam em números absolutos. Em 1970, eram pouco mais de oitenta e cinco milhões, $91,77 \%$ da população; em 1980, seriam cento e cinco milhões, baixando para $88,95 \%$; em 1991, subiu o contingente para cento e vinte e dois milhões, mas com uma proporção de $83,35 \%$; finalmente, em 2000 , se mantêm praticamente o número, com cento e vinte e cinco milhões, com nova queda para $73,89 \%$. Mas aqui é preciso introduzir uma distinção entre os que apenas se declaram católicos e os que têm uma pertença real, o que se chama comumente de católicos praticantes, em número bem menor. Há o caso, bem conhecido, de uma célebre babalorixá baiana que deu a seguinte resposta ao censo: "Sou católica, como todo o mundo". Aliás, em 2000, o número dos que se declararam membros de outras religiões, excetuados os católicos, os evangélicos $(15,57 \%)$ e os sem religião $(7,35 \%)$, foi bem menor do que o previsível: $3,38 \%$. O Centro de Estatística Religiosa e Investigações Sociais (Ceris), em 1999, realizou uma pesquisa sobre o perfil do catolicismo nas seis maiores cidades do país ${ }^{2}$. Os dados modificam um pouco os resultados do censo. Na pesquisa, 67,3\% se declararam católicos, menos do que os 73,89\% do censo, o que é previsível, tratando-

se de áreas urbanas onde os processos de mudança são mais rápidos. É preciso relativizar os dados censais ou as meras avaliações quantitativas. Sabemos que grupos relativamente pequenos mas muito atuantes podem ter mais influência do que maiorias relativamente estáticas. Dom Hélder Câmara falava das "mino- 
rias abraâmicas", capazes de dinamizar e transformar uma realidade, como o fermento na massa, para usar uma imagem tirada do Evangelho.

É interessante notar que a Igreja, ativa desde os tempos coloniais, se identificava tanto com a sociedade mais ampla que sua visibilidade se perdia no conjunto. Da República para cá, com a separação entre a Igreja e o Estado, resistida por setores tradicionais, aquela adquiriu contornos mais precisos e definidos e uma maior liberdade de ação. E foi através de setores dinâmicos em seu interior que sua presença foi se fazendo mais forte. Em 1922, ano de muitas transformações no país - Semana de Arte Moderna, início do tenentismo, fundação do Partido Comunista -, foi criado por Jackson de Figueiredo o Centro Dom Vital, com o incentivo do Cardeal Sebastião Leme. Aí começou uma presença no mundo da cultura, que iria se acentuar com o surgimento da Ação Católica na década seguinte. Alceu Amoroso Lima, crítico literário conhecido com o pseudônimo de Tristão de Athayde, convertido ao catolicismo em 1928 por instigação de Jackson, seria o sucessor deste último no Centro e o primeiro presidente nacional da Ação Catolica. Mas já aqui podemos encontrar diferenças. Na Ação Católica de São Paulo, houve a presença de Plínio Corrêa de Oliveira e de seu assistente eclesiástico, Pe. Castro Mayer, futuro bispo de Campos. Eles se colocavam numa posição ideológica oposta, de um integrismo conservador militante que, anos adiante, produzirá o movimento Tradição, Família e Propriedade. São os tempos de um grande debate em torno ao pensamento do filósofo neotomista Jacques Maritain, ao qual Amoroso Lima estava ligado. Também politicamente havia diferenças. Uma parte significativa de bispos e de leigos favorecia a direitista Ação Integralista Brasileira, criada em 1932 pelo escritor católico Plínio Salgado, próxima ao salazarismo português. Amoroso Lima chegou a sugerir a presença nesse movimento aos católicos que quisessem atuar na vida política ${ }^{3}$. Logo depois, entretanto, tomaria distância desse movimento.

De 1930 a 1945, podemos detectar duas presenças significativas: D. Leme no episcopado, Amoroso Lima no laicato. Mas em 1943 faleceu D. Leme e, logo depois, Amoroso Lima abandonou a direção da Ação Católica, por incompatibilidade com o novo arcebispo do Rio de Janeiro, D. Jayme de Barros Câmara. Vai surgindo nesse momento outra figura, que será central na Igreja dos próximos anos, o então sacerdote Hélder Câmara. Chegou ao Rio de Janeiro vindo de Fortaleza, onde participara da Ação Integralista, da qual também se afastou. Em 1947, foi nomeado Assistente Nacional da Ação Católica. Esta, que nascera calcada na Ação Católica italiana criada pelo Papa Pio XI, evoluiu a partir da influência francesa, belga e canadense, para a Ação Católica especializada, com seus setores, principalmente de jovens, do mundo rural (JAC), estudantil (JEC), independente, isto é, de classes médias (JIC), operário (JOC) e universitário (JUC). Essa Ação Católica, na década de 1950 e início da de 1960, foi responsável por um forte dinamismo da Igreja e por sua presença na sociedade mais ampla. Um movimento teria uma influência particular, a Juventude Universitária Católica 
(JUC), entre 1959 e 1965, quando lançou a idéia de procurar um "ideal histórico" para o Brasil (1960), participando intensamente da política universitária e fornecendo quadros dinâmicos para a educação popular. Atacada por setores tradicionais, foi defendida por D. Hélder Câmara em 1960, em documento que enviou aos bispos: “A JUC [...] está vivendo uma hora plena e merece o apoio e o estímulo do exmo. episcopado"4. A partir da JUC, e já como um movimento não ligado à Igreja, surgiu, em 1962, com a presença de cristãos e não-cristãos, a Ação Popular, grupo político de orientação socialista democrática, nesse momento influenciado pelo personalismo comunitário de Emmanuel Mounier ${ }^{5}$.

Mas já antes, em 1952, por iniciativa de D. Hélder Câmara, nesse momento bispo auxiliar do Rio de Janeiro, foi criada a Conferência Nacional dos Bispos do Brasil (CNBB), da qual ele seria o animador e o primeiro Secretário Geral. É interessante constatar que a CNBB, tão central no cenário brasileiro das próximas décadas, nasceu a partir de experiência da Ação Católica, movimento de leigos e com um núcleo organizativo principalmente de mulheres vindas dela. D. Hélder estará à frente das duas organizações. A Igreja Católica, até então espalhada e isolada localmente através das dioceses, que se ligavam diretamente a Roma, passaria a ter uma estrutura nacional. Isso se deu num contexto mais amplo da sociedade brasileira quando, a partir do último governo Vargas (19501954) até o final da presidência de Juscelino Kubitscheck (1955-1959), tivemos um período que podemos chamar de construção da nação. A Igreja participou desse processo e dessa tendência de unidade nacional.

No começo da década seguinte (1960-1964) a Igreja, através de alguns setores dinâmicos, estaria presente nas atividades da sindicalização rural e de educação popular. Nesse último campo, em 1960, por um convênio entre a CNBB e o governo através do Ministério da Educação, foi criado o Movimento de Educação de Base (MEB), com escolas radiofônicas espalhadas por várias regiões e com programas de alfabetização e de educação fundamental ${ }^{6}$. Foram anos de intensa atividade social e política e a presença da Igreja, por meio de seus movimentos e de seus leigos, se fez fortemente sentir. Mas foi também o tempo de polarizações ideológicas e políticas e isso repercutiu na instituição. Se, de um lado, jovens da Ação Católica e do MEB tinham uma atividade cada vez mais intensa, com o apoio de um grupo de bispos, de sacerdotes e religiosos, por outra parte, se organizou, no sentido oposto, uma resistência às propostas de transformação. Corrêa de Oliveira e dois bispos, Castro Mayer e Proença Sigaud, publicaram um livro contra as mudanças, Reforma agrária, problema de consciência. Tivemos, pois, cristãos dos dois lados do espectro político-ideológico.

Vale analisar, nesses anos, a presença pública da Igreja através de alguns bispos e da CNBB. Já em 1950, o bispo de Campanha, Minas Gerais, Dom Inocêncio Engelke, ligado à Juventude Agrária Católica, tinha lançado sua cartapastoral: Conosco, sem nós ou contra nós se fará a reforma rural. O tema, sempre polêmico, como foi dito acima, dividiria a Igreja. Reuniões de bispos do Rio 
Grande do Norte (1951), da Amazônia (1952 e 1957) e do Vale do São Francisco (1952), trataram dos temas do desenvolvimento, da reforma agrária e das migrações. Em 1956, realizou-se uma reunião no nordeste, com dirigentes da CNBB e do governo, a qual, segundo testemunho do próprio presidente Kubitschek, esteve na origem da criação da Superintendência do Desenvolvimento do Nordeste (Sudene):

esta iniciativa do Governo Federal é devida, força é proclamar, à inspiração caridosa da Igreja e ao desejo enérgico de salvar da miséria tantos valorosos patrícios nossos... Foram Vossas Excelências, Senhores Bispos, os animadores e promotores do trabalho que estamos começando a realizar... As forças espirituais aqui reunidas, com os olhos voltados para a realidade essencial dos problemas, reclamaram e pediram que as soluções para a libertação deste pedaço imenso do Brasil fossem consideradas assuntos prioritários (JK, encontro com bispos do nordeste, 1959).

Nesses anos de rápidas transformações e intensos debates, foi ficando evidente a estrutura social cada vez mais desigual e polarizada do Brasil. País em desenvolvimento, com capas enormes de pobreza e, nos termos da época, dramática marginalização social. Uma mensagem da Comissão Central da CNBB de julho de 1962 indicava, em cores fortes:

Ninguém desconhece o clamor das massas que, martirizadas pelo espectro da fome, vão chegando, aqui e acolá, às raias do desespero... o povo da cidade e dos campos começa a compreender que, sem a participação na vida das instituições e da própria sociedade, jamais será libertado do estado de ignomínia em que se encontra.

O Estado tratava de ir desenvolvendo suas políticas nas áreas de educação, saúde, habitação e a sociedade debatia as chamadas "reformas de base". Em 30 de abril de 1963, exatamente um ano antes do golpe de Estado, os bispos voltaram ao problema em nova mensagem:

Nossa ordem é, ainda, viciada pela pesada carga da tradição capitalista, que dominou o Ocidente nos séculos passados. É uma ordem de coisas na qual o poder econômico, o dinheiro, ainda detém a última instância das decisões econômicas, políticas e sociais. Exigem-se profundas e sérias transformações.

E enumerava a seguir a questão rural, a reforma da empresa, a reforma tributária, a reforma administrativa, a reforma eleitoral e o problema educacional. Agenda, aliás, quarenta anos depois, de uma atualidade impressionante e que mostra o pouco que se avançou desde então em matéria de políticas sociais e a centralidade que continuam ocupando até hoje as políticas econômicas... ${ }^{7}$ Nesses anos, produziu-se uma enorme fermentação social na sociedade, polarizando-se as opções ideológicas e políticas. Dirigentes cristãos estiveram presentes nas atividades de educação popular (iniciativas do Movimento de Educação de Base da CNBB, do Movimento de Cultura Popular de Recife, das experiências de Paulo Freire...), de sindicalização rural e em diferentes mobilizações sociais. 
O golpe de 1964, logo depois, tratou de interromper esse processo incômodo para o sistema.

Assim, a Igreja, como instituição, por meio da CNBB, às vésperas de abril de 1964, tomava posição a favor das reformas sociais. Um bom número de seus membros - especialmente militantes ou ex-militantes da Ação Católica - participava dos processos de mudança. Mas não podemos esquecer que outros católicos se mobilizaram em direção contrária. Em começos de 1964, depois de uma Cruzada do Rosário em família, liderada pelo sacerdote americano Pe. Peyton, surgiram as Marchas com Deus pela Família e pela Liberdade, com apoio de figuras importantes do episcopado e do clero, no combate ao que julgavam ser o perigo da subversão da ordem. No momento do golpe, a Igreja, no dizer de um autor, ficaria "na corda bamba" . Vários cristãos seriam presos, se asilariam em embaixadas ou partiriam para o exílio, enquanto outros fariam parte do primeiro governo militar ou dos órgãos de repressão. A própria CNBB, em sua Mensagem de 27 de maio de 1964, estranhamente declarava:

Agradecemos aos militares, que com grave risco de suas vidas (sic!) se levantaram em nome dos supremos interesses da Nação e gratos somos a quantos concorreram para libertar-nos do abismo iminente.

Mais adiante, entretanto, faria uma defesa corporativa de alguns de seus membros:

Não aceitamos e nem podemos aceitar nunca acusação injusta, generalizada, gratuita, velada ou explícita, pela qual bispos, sacerdotes, fiéis ou organizações, como, por exemplo, a Ação Católica e o MEB são comunistas ou comunizantes.

Não há que esquecer que os conflitos sociais, que atravessam a sociedade, também dividem a Igreja e aí refratam seu espectro ideológico. Esta é uma instituição inserida na vida social e sujeita às pressões de interesses contraditórios.

Porém, nos vinte anos seguintes do regime militar (1964-1985), quando se fecharam no país lugares de articulação política, sindical e social, a Igreja foi um espaço de relativa liberdade de organização e de ação. A CNBB e alguns bispos foram, o que se chamou depois, "a voz dos sem voz”. Nesses anos surgiram a Comissão da Pastoral da Terra (CPT) e o Conselho Indigenista Missionário (Cimi) e se desenvolveram a pastoral operária e as pastorais de juventude. Mas a presença decisiva foi das Comunidades Eclesiais de Base (as CEBs), que foram brotando em diferentes igrejas locais (Vitória, Goiás, Crateús e, logo depois, na periferia de São Paulo). Eram pequenos grupos de cristãos de setores populares que se reuniam para momentos de oração e de celebração de sua fé, mas também de reflexão sobre seus problemas concretos de trabalho, saúde, educação, direitos humanos etc. Havia uma ligação muito profunda entre fé e vida concreta, que estaria na base da reflexão latino-americana desses anos, em torno à Teologia da Libertação. 


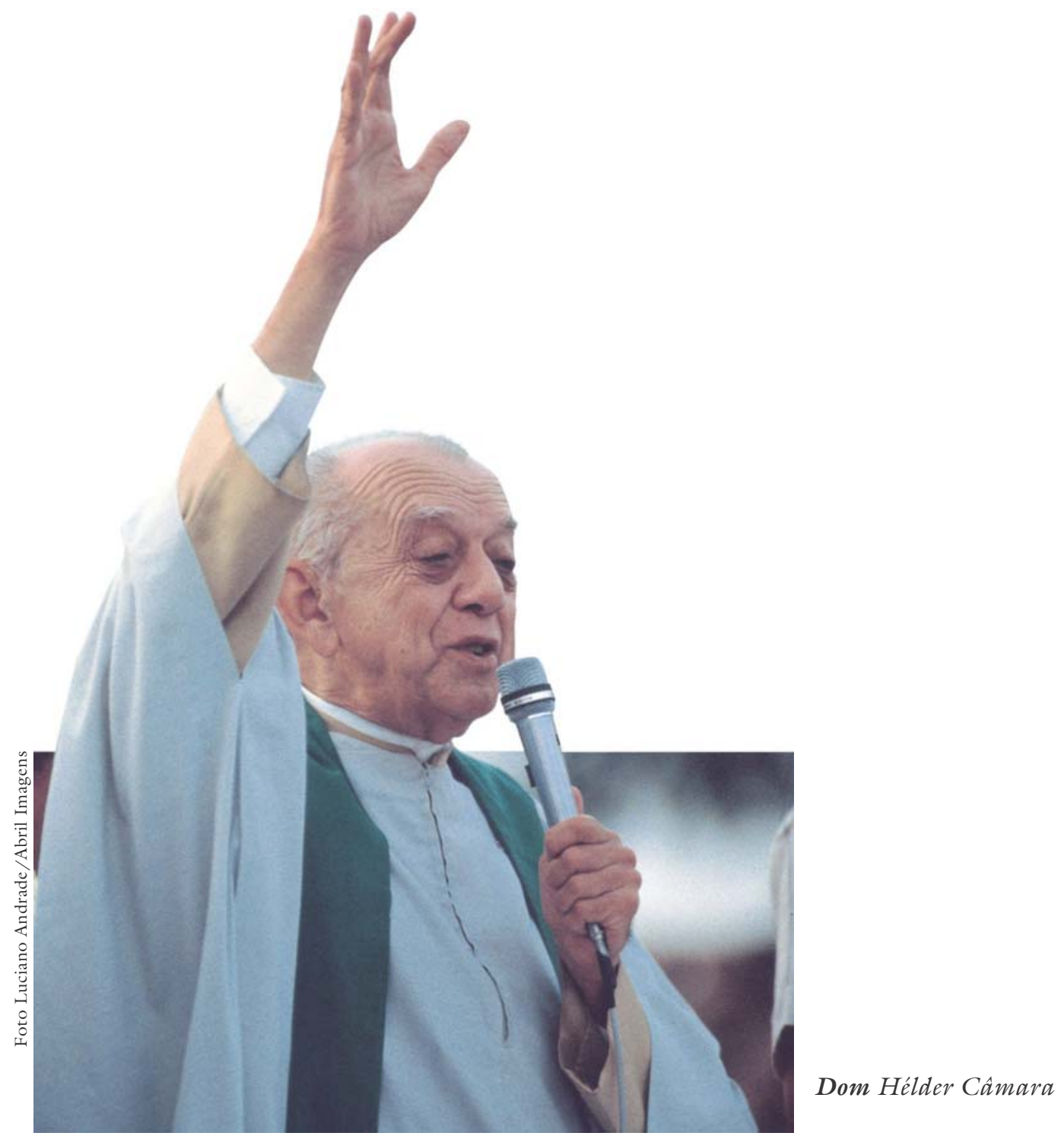

Aliás, isso se deu no contexto mais amplo de toda a região, num período que vai da reunião dos bispos latino-americanos em Medellín (1968) à seguinte, em Puebla (1979). Deve colocar-se, além disso, num cenário eclesial mais geral, da Igreja Católica em termos internacionais, depois do pontificado de João XXIII e do pós-Concílio Vaticano II; era também um tempo de mudanças em termos mundiais, em torno a 1968 e à rebelião dos jovens e da contra-cultura, que sinalizou um possível momento de crise da modernidade e de esgotamento do que se chamaram os "trinta anos gloriosos", depois da Segunda Guerra Mundial. É significativo que a reunião de Medellín ocorreu no mesmo ano de 1968 e três anos depois do concílio. Nela foi indicado o pobre como ator central na vida da Igreja e da sociedade, foram denunciadas as estruturas de desigualdade social (pecado social) e foi anunciado um horizonte futuro de libertação, no seu senti- 
do mais amplo e integral. A reunião seguinte de Puebla, dez anos depois, confirmou Medellín e afirmou novamente a "opção preferencial pelos pobres", apoiando a experiência das CEBs, "expressão do amor preferencial da Igreja pelo povo simples" (nº 643). De 1968 a 1979 tivemos o que considero uma "década gloriosa", da vida eclesial na América Latina. Foi, em contraste, um tempo terrível do ponto de vista político, com golpes e ditaduras no Brasil, no Chile, na Argentina e no Uruguai. Mas a Igreja esteve presente, em muitos países, na defesa dos direitos humanos (Brasil, Chile), ainda que tenha havido silêncios e omissões graves (Argentina). Essa Igreja, acusada tantas vezes de chegar atrasada ao cenário dos conflitos sociais dos últimos séculos, parecia então bastante adequada à consciência histórica desses tempos, pelo menos em alguns países e setores mais atuantes 9 .

A problemática rural foi sempre um dos eixos centrais da questão social brasileira. A CNBB, em sua Assembléia de 1980, aprovou uma declaração sobre a Igreja e os problemas da terra, que despertou fortes reações nos ambientes conservadores e nos setores dirigentes do sistema, por relativizar, a partir de sua doutrina mais tradicional, o direito de propriedade, subordinando-o ao uso e destinação universal dos bens. Suas Diretrizes da ação pastoral de 1983 e de 1987, poriam ênfase na necessidade de transformações estruturais, da mesma forma que a declaração de 1988, Igreja: comunhão e missão na evangelização dos povos, no mundo do trabalho, da política e da cultura ou, no ano seguinte, Exigências éticas da ordem democrática. Nesse último documento se pode ler: "A democracia não se realiza, de fato, quando o sistema econômico excluir parcelas da população dos meios necessários a uma vida digna" ${ }^{\prime \prime}$.

Vale analisar aqui, voltando um pouco atrás, a relação entre a Igreja e a política. No caso brasileiro, tínhamos herdado o regime do padroado português, com as ambigüidades que levaram à "questão religiosa" ao final do período imperial e à prisão de dois bispos que defendiam os direitos e a liberdade da Igreja. Com a República, veio uma separação imposta. Essa separação teve um resultado positivo: a relação principal não seria, desde então, apenas entre Igreja e poder político, mas entre Igreja e sociedade. Há um texto lúcido e antecipador do Pe. Júlio Maria, nos últimos meses do século XIX, em que ele quis

substituir às questões políticas erroneamente predominantes nos governos, nos parlamentos e nos jornais, a questão social, que é a questão por excelência, porque ela afeta os interesses fundamentais do homem e da sociedade; [...] mostrar aos pequenos, aos pobres, aos proletários, que eles foram os primeiros chamados pelo Divino Mestre, cuja Igreja foi logo, desde seu início, a Igreja do povo $[\ldots]^{11}$.

Houve, assim, um deslocamento do poder político para as necessidades da sociedade. Isso será decisivo numa reflexão sobre a presença social e política da Igreja brasileira durante o século XX.

No Brasil, a intervenção da Igreja, como instituição, no campo diretamente político, teve dois momentos principais nas últimas décadas. Nos anos de 
1930, foi criada a Liga Eleitoral Católica, próxima à Ação Católica de então (Alceu Amoroso Lima foi dirigente nacional de ambas). A LEC analisava os candidatos a postos eleitorais, a partir de alguns princípios ou exigências que julgava indispensáveis para os interesses da Igreja (indissolubilidade do matrimônio, ensino religioso nas escolas...) e recomendava ou vetava esses candidatos. Isso provocou muitas reações na sociedade, com críticas à ingerência da Igreja na vida partidária. E na mesma Igreja começou um debate sobre se não seria mais apropriada a presença na política numa dimensão mais ampla do que a eleitoral, em função do bem comum da sociedade e a partir de alguns princípios e valores universais. A intervenção na política não se reduziria então a juízos durante as eleições, mas se daria ao nível da consciência ética, em ações e posicionamentos na sociedade (polis), nos processos de tomada de decisão coletiva e na gestão da coisa pública. Isso deu lugar à forte presença da Igreja institucional na vida nacional, referida anteriormente.

Já indicamos também a intervenção da Igreja no período que vai até 1964. Vieram logo os tempos terríveis do período autoritário. No fechamento de tantas áreas da vida pública, o espaço eclesial permaneceu como lugar privilegiado de reflexão, de denúncia, de anúncio e de propostas concretas. Documentos e estudos da CNBB foram assinalando prioridades para a agenda do país: Exigências cristãs de uma ordem politica (doc. 10), Igreja e problemas da terra (doc. 17), Reflexão cristã sobre a conjuntura política (doc. 22), Solo urbano e ação pastoral (doc. 23), Nordeste: desafio à missão da Igreja no Brasil (doc. 31).

Além disso, por meio das Comissões de Justiça e Paz, a Igreja esteve também presente na defesa valente dos direitos humanos e na denúncia à repressão e à tortura, sem restrições às diferentes crenças e ideologias. Há que salientar aqui a desassombrada atitude do Cardeal D. Paulo Evaristo Arns. Já desde seu tempo como bispo auxiliar de São Paulo vinha denunciando as torturas e defendendo os presos políticos. Como arcebispo titular, logo depois, enfrentou várias vezes o comando da segunda região militar. Numa ação ecumênica, atuou em conjunto com o pastor Jayme Wright e com ele esteve à frente de uma ampla comissão que preparou a memória desses delitos e que produziria mais adiante o livro Brasil: tortura nunca mais ${ }^{12}$. D. Hélder Câmara, desde seu discurso de posse em Recife, em março de 1964, não cessou de denunciar o autoritarismo e as violações de direitos. Seu nome desapareceu dos meios de comunicação brasileiros por imposição da censura, ao mesmo tempo em que alcançou enorme repercussão internacional; o governo pressionou e conseguiu que não lhe fosse concedido o Prêmio Nobel da Paz ${ }^{13}$. Outros bispos como D. Waldyr Calheiros, D. Antônio Fragoso, D. Tomas Balduíno ou D. Pedro Casaldáliga foram testemunhas determinantes nesses anos difíceis ${ }^{14}$. Para este último foi tentada, inclusive, a expulsão do país. Um bispo de análise penetrante, D. Cândido Padim, desocultou os supostos autoritários e anticristãos da doutrina de segurança nacional ${ }^{15}$. 
Depois da abertura democrática, a presença da Igreja seguiu vigilante no trato da coisa pública. Lembro, entre outras, duas declarações da CNBB: Exigências éticas da ordem democrática (27aa assembléia de 1989 - doc. 42) e Ética: pessoa e sociedade ( $31^{\underline{a}}$ Assembléia de 1993 - doc. 50). Na primeira está dito claramente:

Não cabe à autoridade da Igreja propor modelo alternativo de organização da sociedade ou formular diretrizes de política econômica e social. Contudo, por seu esforço em ouvir "os clamores do povo", o episcopado brasileiro tem chamado a atenção do governo e da sociedade sobre questões que lhe parecem particularmente urgentes e prioritárias ( $\left.\mathrm{n}^{\mathrm{O}} 108\right)$.

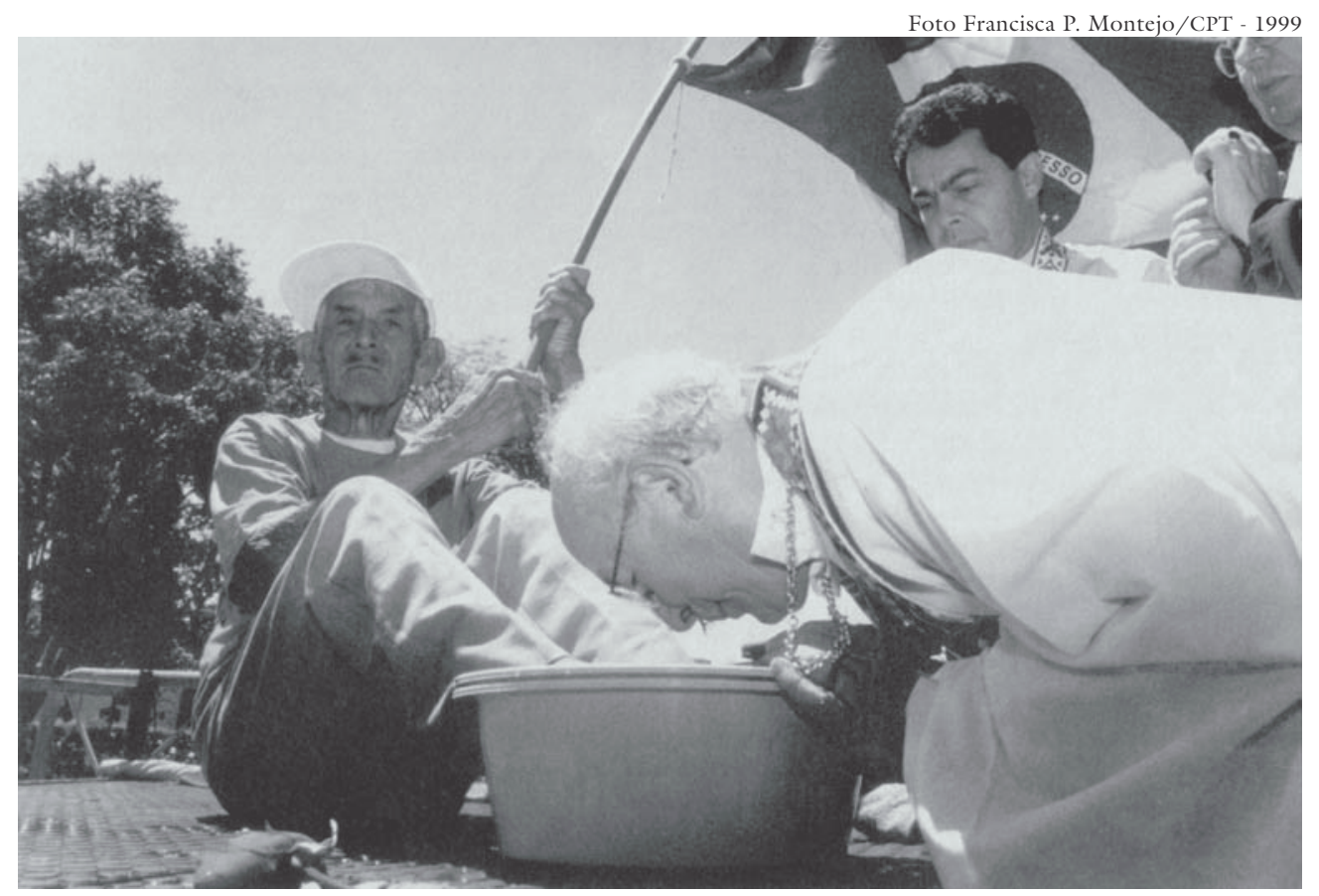

D. Tomas Balduino lava os pés do sem-terra mais velho que participou da marcha para Brasilia.

E enumera nos itens seguintes algumas delas: necessidade de uma política agrícola e a execução imediata de uma reforma agrária; garantir uma justa distribuição do solo urbano; preservar e renovar o meio ambiente; apoio à luta dos trabalhadores e incentivo à sua participação na sociedade e na empresa; função social da empresa; auditoria da dívida externa" ( $n^{\circ}$ 109-115).

O documento de 1993, procurando respostas concretas para os desafios da realidade, chama fortemente a atenção para um projeto de sociedade iluminada pelos princípios de solidariedade e de participação e insiste na ética na política, na economia e nos meios de comunicação social, fazendo uma denúncia firme da corrupção presente na sociedade (anexo II, 1.1, 1.2, 1.3).

Mais recentemente estão a densa declaração, Eleições 2002 - as diretrizes para as comunidades eclesiais (doc. 67) e a proposta de um Mutirão Nacional para a Superação da Miséria e da Fome, resultado do documento Exigências 
evangélicas e éticas da Assembléia de 2002 da CNBB, antecipando-se assim às prioridades governamentais do governo Lula no ano seguinte.

Tudo isso para indicar que há uma tradição, constituída e amadurecida, de voz ativa e de presença permanente da Igreja no que se refere à coisa pública, isto é, à vida política em seu sentido mais amplo e abrangente.

E a participação direta dos cristãos na vida política? À diferença de outros países (Itália, Chile, Venezuela), não tivemos a criação de um forte partido democrata-cristão que aglutinasse a presença político-partidária dos católicos. Nos anos de 1920, Jackson de Figueiredo pensou na criação de um partido católico, no que foi dissuadido por D. Sebastião Leme ${ }^{16}$. É verdade que, no começo da década seguinte, alguns católicos, com o apoio de dirigentes leigos, do clero e de alguns bispos, se encaminharam para a Ação Integralista, como foi indicado anteriormente. A cruzada do General Franco, na Espanha, estava na ordem do dia, apesar das distâncias que, frente a ela, logo tomariam intelectuais católicos da envergadura de Bernanos, Mauriac e, principalmente, Jacques Maritain.

A influência de Maritain foi decisiva, nesse momento, para a superação de uma visão clássica de cristandade, ainda que fizesse a proposta ambígua de uma "nova cristandade"17. Mas iria introduzir a célebre distinção entre "agir como cristão" (opção individual dos cristãos na política) e "agir enquanto cristão" (ação da Igreja como tal). A partir de seu pensamento, surgiram em vários países partidos de inspiração cristã. No Brasil, tivemos inclusive um PDC, depois de 1945, ainda que de presença discreta.

Minha geração da JUC (e depois da primeira AP) teve uma influência diferente, de outro intelectual católico francês, Emmanuel Mounier ${ }^{18}$. Para ele, não havia uma relação imediata e dedutiva entre cristianismo e opção política: não se poderia ser monarquista porque cristão ou socialista porque cristão. O socialismo de Mounier não era conseqüência direta e inevitável dos princípios cristãos, mas estes orientavam uma reflexão e um discernimento com a utilização dos instrumentos das ciências humanas e das vivências de práticas políticas e sociais concretas $^{19}$. Ao lado de Mounier, foi decisiva para nós a reflexão do pensador e mestre, Pe. Henrique C. de Lima Vaz. Em lugar de procurar dedutivamente construir um "ideal histórico" de inspiração cristã, ele nos indicava a urgência da inserção na "consciência histórica" contemporânea, com seus desafios, riscos, virtualidades e novas circunstâncias ${ }^{20}$. A prática política seria uma tarefa comum de cristãos e de não-cristãos, aqueles procurando apoio no Evangelho, mas sem querer apropriar-se dele ou reduzi-lo a suas opções políticas particulares. Haveria uma irredutibilidade da fé a uma posição político-ideológica determinada, ainda que esta precisasse daquela como iluminação. Uma conseqüência seria um pluralismo político e a militância de cristãos em vários partidos e movimentos.

Temos hoje a presença de católicos numa grande gama partidária. Mas uma situação particular deve ser sinalizada. Em 1980, foi criado o Partido dos Trabalhadores. Ali confluíram várias tendências, de lideranças sindicais, de movi- 
mentos sociais, de correntes da esquerda tradicional e também de práticas pastorais. Isso não significou um exclusivismo da militância católica em direção a um partido, mas uma porção significativa dela, ligada a práticas eclesiais comprometidas com a vida social, encontrou fortes afinidades entre sua ação na sociedade e a nova proposta partidária. Anos depois, em 1987, Frei Clodovis Boff lançou um questionamento, indagando se a passagem de uma ação eclesial para uma opção partidária deveria ser um passo individual ou coletivo. Isto gerou um amplo debate, com a participação de muitos que estavam presentes nas assessorias aos movimentos sociais e pastorais. Vários insistiram na importância da opção pessoal de cada um ${ }^{21}$.

Avaliando a situação atual da Igreja, há que evitar algumas simplificações. Algumas análises, apressadamente, insistem num possível recuo das pastorais sociais e das CEBs e na vitalidade dos novos movimentos religiosos, especialmente os carismáticos católicos. É verdade que estes últimos, ao que tudo indica, são os que mais têm crescido. Talvez isso corresponda a uma sensibilidade particular dos dias atuais, no que alguns - ao meu ver inapropriadamente - chamam de tempos pós-modernos. Uma insegurança percorre a sociedade, que procura um refúgio na subjetividade e no emocional. Projetos sociais alternativos nem sempre são bem percebidos. Nesse sentido há, freqüentemente, um refluxo para a interioridade e pode perder-se uma dimensão social de solidariedade e de anseio de transformação. Mas isso não impede que vários grupos eclesiais e movimentos sigam na linha de procurar caminhos de renovação da Igreja e da sociedade, num exercício de justiça social e de solidariedade. A realidade não se parece a uma gangorra, em que uns sobem em detrimento de outros que descem. Tendências opostas podem ter crescimento, ainda que em ritmos diferentes. Não se trata de um jogo de soma zero, em que uns anulam os outros. Se o movimento carismático aumenta, isso não indica que as pastorais sociais e as CEBs declinem. Analisando estas últimas, a partir da presença nos seus Encontros Intereclesiais dos últimos anos - São Luís, 1997 ou Ilhéus, 2000 -, pode-se constatar uma implantação nacional maior do que no passado e uma maior distribuição geográfica. Em algumas regiões pioneiras pode ter havido crises e declínio, mas as CEBs se espalharam, por exemplo, pelo sul e centro-oeste ${ }^{22}$.

Uma recente pesquisa sobre "o cotidiano das CEBs", confirma e fortalece muito do que afirmo acima. Num seminário de preparação para o $10^{\circ}$ Interclesial de Ilhéus, alguns participantes - entre os quais o autor deste texto, que tomou a iniciativa - propuseram "ver como as CEBs estão de fato e não apenas como aparecem nos Intereclesiais”. O Iser Assessoria, com ampla experiência de acompanhamento eclesial, tomou a si a tarefa e realizou, em 2003, uma cuidadosa e bem formulada pesquisa, com um levantamento em 67 CEBs, 31 do Rio de Janeiro e 36 de Minas Gerais e estudo de caso em quatro comunidades, duas urbanas (Duque de Caxias e Ipatinga) e duas rurais (Sapucaia e Campos Gerais). Recolho algumas conclusões, de uma primeira redação. Ainda que não se possa generali- 
zar para todo o universo, indicam claramente algumas tendências. As CEBs aparecem na pesquisa como uma experiência consolidada. A maior parte tem entre vinte e trinta anos e dois terços delas considera que estão crescendo. Aliás, crescem mais aquelas que abrem espaço para os jovens na base, ainda que este espaço seja reduzido nas instâncias de poder. As CEBs estão majoritariamente constituídas por membros das classes populares, com presença de classe média e médiabaixa; os miseráveis aparecem como exceção. As mulheres são maioria (62\%) e começam a ter um peso maior em sua direção, o que contribui para um certo empoderamento delas na Igreja e na sociedade. Há uma centralidade da dimensão celebrativa, como espaços de comunhão e de participação. As CEBs continuam a exercer um papel ativo na sociedade, desde atividades assistenciais, até mobilizações e engajamento em associações, sindicatos e partidos, assim como em campanhas nacionais e em conselhos municipais ${ }^{23}$.

É inquestionável que a Igreja Católica, como instituição, vive uma conjuntura menos aberta do que aquela do imediato pós-concílio e dos tempos entre Medellín e Puebla. Como referido anteriormente, em 1968, a Igreja latino-americana, no clima da época, esteve à frente na consciência crítica da realidade. O Brasil desempenhou então um papel decisivo. Mas a situação atual da instituição indica alguns impasses e recuos. Isso se insere em um contexto eclesial mais amplo, neste quarto de século do pontificado de João Paulo II, sensível a temas de justiça social e de paz, mas conservador em doutrina e disciplina interna. Um autor se referiu ao "inverno na Igreja" 24 . O número de Comunicações do Iser, no mesmo ano, trazia a indicação: "estação de seca na Igreja"25. Um livro recente de Peter Steingels, sobre a Igreja nos Estados Unidos, tem um título bastante severo: Um povo à deriva ${ }^{26}$. E para este analista a crise não começou há pouco com os escândalos da pedofilia, mas bem mais atrás, em 1968, nos tempos da encíclica de Paulo VI, Humanae Vitae, sobre a temática da contracepção. O filósofo italiano Pietro Prini, num livro provocador, falou de um cisma oculto ou subterrâneo (scisma sommerso), a partir de uma quebra de comunicação entre Igreja e sociedade. Assinala:

o aggiornamento da Igreja no mundo contemporâneo, iniciado no concílio e continuado por uma geração de teólogos excepcionalmente preparada e aberta, foi estancado nos últimos anos, logo quando era necessário ter a coragem de confrontar a Fé com os resultados doutrinários e metodológicos das ciências antropológicas de hoje ${ }^{27}$.

Essa crise se deu em relação a vários processos de transformação, dos novos movimentos sociais, da ecologia, da subjetividade, da bioética, do gênero e da sexualidade. Inclusive, no mesmo ano de Medellín, em 1968, com a Humanae Vitae, que referendou a posição minoritária da comissão pontifícia que estudava a matéria da reprodução humana, houve um congelamento doutrinário, que foi produzindo nos anos seguintes uma defasagem crescente entre orientações doutrinais e as práticas dos fiéis (e inclusive atitudes pastorais "de fato") ${ }^{28}$. A 
Igreja, até hoje, tem uma certa dificuldade para debater, com liberdade e ousadia, os novos problemas da subjetividade e da sexualidade, ainda que desde bem atrás muitos teólogos, especialmente no mundo anglo-saxão, viessem pedindo para levar a sério a idéia do "desenvolvimento da doutrina", na linha indicada um século antes pelo Cardeal Newman ${ }^{29}$. Muita coisa ficou reprimida, oculta e empurrada para a semiclandestinidade dos comportamentos individuais ${ }^{30}$. Os escândalos atuais na Igreja apenas tornam visíveis a ponta de um iceberg de questões mal digeridas e de difícil discernimento, num clima de medos e de suspeições.

Internamente, pois, a Igreja deve enfrentar, nos próximos anos, alguns desafios significativos. A imprensa tem insistido nos casos da pedofilia, mas o problema é mais amplo e tem a ver, entre outros temas, com a maneira com a qual ela trata do problema da sexualidade. O Ceris, em 2003, realizou uma ampla pesquisa, "o perfil do presbítero brasileiro", a pedido do Conselho Nacional dos Presbíteros, entrevistando 758 sacerdotes em todo o país. Sobre um total de 16.634 padres, uma amostra representativa de $11 \%$ teria exigido 1.831 respostas. De fato, o número foi menor. Muitos dos entrevistados não puderam ou não quiseram responder. Mas em todo o caso os dados, embora não possam ser generalizados para todo o universo, indicam tendências. Ali foram inclú́dos muitos temas da vida sacerdotal, desde as origens de sua vocação, formação, relação com leigos e integração psico-afetiva. É interessante constatar que este último ponto foi o que chamou a atenção dos meios de comunicação social e de setores da própria Igreja, especialmente a pergunta em que $41 \%$ dos entrevistados responderam ter tido envolvimento afetivo com mulheres. Há que precisar que isso não implicava necessariamente relações sexuais em sentido estrito, ainda que a imprensa, com certo escândalo, tenha reduzido a resposta a esse último ponto. Esses dados correspondem, aliás, ao que o sentido comum e uma prática de vida já indicavam ${ }^{31}$. Mas a reação e o mal-estar em certos meios da instituição foi grande, porque tocava, de certa maneira, num ponto que a Igreja tem grande dificuldade em enfrentar: o celibato sacerdotal obrigatório. Este está fixado por uma norma da Igreja ocidental no milênio anterior, sujeita a revisão, pois tratase de uma medida disciplinar que não toca em nenhum ponto do dogma. Tudo indica que, mais dia menos dia, o magistério e um possível futuro concílio terão de revisar essa orientação.

O outro tema critico é o relativo ao gênero. Novos sujeitos históricos deverão ser levados em conta. Entre eles, na sociedade do século $\mathrm{XX}$, as mulheres foram as mais contestadoras e desafiantes. Os movimentos femininos e feministas são os subversivos por excelência, já que põem o dedo na mais antiga das dominações, a patriarcal. Num primeiro momento, através das sufragistas, exigiram principalmente igualdade de direitos. Freqüentemente, o dominado, para achar espaço, tem de igualar-se e seguir o modelo do dominador. Igualdade sim, mas com direito à diferença, foram descobrindo, sem precisar copiar e repetir o mundo masculino. Rose Marie Muraro fez essa crítica num de seus livros ${ }^{32}$. 
E isso encaminha ao tema das mulheres na Igreja. Elas são maioria nas comunidades e nos serviços, mas continuam subordinadas aos clérigos. Leigas, religiosas, membros de institutos seculares, representam talvez, hoje, o setor mais vital na vida eclesial. A velha tradição patriarcal - de clérigos celibatários - resiste mais do que na sociedade. Mas não poderá opor-se por muito tempo às pressões. No Encontro Intereclesial das CEBs de 1992, em Santa Maria, o plenário das mulheres pediu para participar "em todas as instâncias dos ministérios”. No sínodo dos bispos em Roma, em 1971, o cardeal canadense George B. Flahiff manifestou-se decididamente em favor do sacerdócio da mulher ${ }^{33}$. Uma decisão mais recente de um dicastério romano, com aprovação papal, vedando o acesso das mulheres ao sacerdócio, está sendo apresentada como irreversível. Mas não se revestiu do caráter solene das proclamações dogmáticas. Sem base escriturística e com uma tradição mais cultural que doutrinária, é passível de reexame mais adiante.

Temos hoje uma Igreja centrada nos clérigos. Na História da Igreja de Fliche e Martin, o volume $\mathrm{n}^{\mathrm{O}}$ 7, que trata do século $\mathrm{X}$, tem um título curioso: $A$ Igreja em poder dos leigos. Mas aí não se quer dizer que a Igreja estava nas mãos dos cristãos comuns, mas simplesmente dos leigos realmente poderosos, e principalmente de umas poucas famílias do patriciado romano. Logo depois, o grande esforço da reforma gregoriana, no começo do segundo milênio, foi de libertála desses leigos poderosos e dos abusos que daí provinham. Estruturou-se assim uma Igreja dos clérigos, que chega até nós, nos alvores do terceiro milênio. Tivemos então mil anos dessa Igreja dos clérigos. E foi em torno destes últimos que se articulou a instituição, para livrá-la do poder temporal. Mas o que num primeiro momento foi libertação, logo depois se converteria em criação de novos privilégios e afastamento de muitos atores eclesiais. E o curioso era que o não-clérigo correspondia à maioria esmagadora dos membros da Igreja, colocada numa situação de relativa marginalidade ou, pelo menos, carente de iniciativa e com participação bastante limitada.

No século passado, o papa Pio XI indicou que a Ação Católica era "a participação dos leigos no apostolado hierárquico da Igreja”. A frase surpreendeu muita gente. Os leigos chegavam até o interior do espaço da hierarquia, chassegardée dos clérigos. O papa seguinte, Pio XII, já foi bem mais cuidadoso, e em vez de participação preferiu falar de colaboração dos leigos. Houve um certo recuo semântico e real. Participação é mais forte do que colaboração. Na preparação do atual Código de Direito Canônico, num dos anteprojetos, uma das propostas falava da participação dos leigos no poder de governo ou de regime da Igreja. No código aprovado vamos encontrar apenas a palavra cooperação ${ }^{34}$.

É verdade que se avançou quando, do Vaticano II para cá, passamos do mundo eclesiástico dos clérigos para o mundo eclesial do Povo de Deus. E a categoria eclesial vai superando a categoria eclesiástica, bem mais limitada. Mas ainda falta muito por caminhar. Havia, até pouco tempo atrás, uma expressão bastante eloqüente nos atos falhos dos meios eclesiásticos: quando um clérigo 
deixava o sacerdócio ele era reduzido ao estado leigo, isto é, rebaixado nos graus promocionais.

A Igreja Católica vive hoje uma contradição interna. Uma instituição fortemente hierarquizada, onde a noção de autoridade tem um papel destacado, insiste nos documentos do magistério na importância da participação na sociedade; ao mesmo tempo, no seu interior, vêm se desenvolvendo nos últimos anos práticas participativas em experiências pastorais. Os membros da Ação Católica de juventude foram incentivados a agir no seu meio de vida - mundo operário, rural ou estudantil. Ao voltarem-se para a Igreja logo depois, por uma exigência de coerência, pediram compartir responsabilidades e ter ali uma parte ativa. Nem sempre puderam fazê-lo e isso foi causa de crises e de tensões desses movimentos em vários países ${ }^{35}$.

Talvez, hoje, estejamos mais próximos da Igreja do começo dos anos de 1950, final do pontificado de Pio XII, do que dos tempos do papa João XXIII e do Vaticano II. Naquele primeiro momento, o Papa, centralizador, tratava de quase todos os temas, inibindo um debate e seus silêncios e omissões também pesavam bastante. Teólogos (Congar, de Lubac) foram silenciados, depois da encíclica Humani Generis de 1950. Mas logo adiante, com um velho e simpático papa aparentemente apenas de transição, do qual não se esperava muito, arejouse a Igreja - aggiornamento foi a expressão de então - e velhas idéias foram espanadas da poeira das rotinas, da autocensura e dos medos. João XXIII, inesperadamente, para espanto e temor da cúria romana, em janeiro de 1959, convocou um concilio ecumênico.

Nos últimos tempos volta-se a falar da necessidade de um futuro concílio, para enfrentar temas por agora congelados. Foi eloqüente uma alocução do cardeal Martini no sínodo dos bispos europeus em 1999. Indicou alguns temas que a Igreja deveria enfrentar: a posição da mulher na sociedade e na Igreja, a participação dos leigos em responsabilidades ministeriais, a sexualidade, o matrimônio e o ecumenismo $^{36}$. Em maio de 2001, começou a circular uma carta aberta ao Papa João Paulo II, sugerindo a convocação de um novo concílio ecumênico, "em continuidade com o espírito do Vaticano II", que permitisse à Igreja Católica enfrentar "os grandes desafios da humanidade, em particular dos pobres, num mundo em rápida transformação e cada vez mais inter-relacionado”. Sugeria que,

com as novas facilidades de comunicação e intercâmbio... seja concebido como processo conciliar, participativo e co-responsável [...] durante um tempo suficientemente amplo e com uma metodologia apropriada, para que a comunidade dos crentes possa pronunciar-se...

Assinaram 34 bispos do Brasil, Argentina, Bolívia, Equador, Guatemala, México, Peru, Espanha e Japão (25 bispos eram brasileiros ${ }^{37}$ ), 917 sacerdotes, 1.471 religiosos e religiosas, 7.397 leigos e leigas e mais 342 sem especificação ${ }^{38}$. Em recente livro recolhi material a respeito. Mais importante do que um concílio, talvez um pouco prematuro na atual situação, será um processo de preparação e de debates, que enfrente com coragem os desafios e os impasses atuais ${ }^{39}$. 
Muitas análises de conjuntura se centram apenas nos aspectos institucionais e nas estruturas de poder eclesiástico e suas conclusões são freqüentemente pessimistas. É necessário, porém, estar atento ao mundo eclesial mais amplo e às tendências e práticas nas igrejas locais. Aí descobrimos dinamismos latentes e experimentações significativas que podem levar a revisões futuras nas orientações gerais da instituição. João XXIII falou do Vaticano II como "uma flor de inesperada primavera". Não poderemos ter surpresas pela frente? O que hoje são grupos pequenos - as "minorias abraâmicas" referidas anteriormente - podem abrir caminho a uma nova maneira da Igreja ser no futuro. Fica a pergunta, que é

muito mais uma aposta que uma certeza: como se desenhará, aos poucos, neste terceiro milênio, uma Igreja mais transparente, participativa e comunicadora da Boa Nova (Evangelho) para os novos tempos?

\section{Notas}

1 Émile Poulat, Histoire, dogme et critique dans la crise moderniste, Paris, Casterman, 2002.

2 Ceris, Desafios do catolicismo na cidade, São Paulo, Paulus, 2002.

3 Alceu Amoroso Lima, Indicações políticas, Rio de Janeiro, Civilização Brasileira, 1936, pp. 187 e 193.

4 Para esse movimento, ver L.A. Gómez de Souza, A JUC: os estudantes católicos e a política, Petrópolis, Vozes, 1985.

5 Luiz Gonzaga de Souza Lima, Evolução política dos católicos e da Igreja no Brasil, Petrópolis, Vozes, 1979; Giovanni Semeraro, A primavera dos anos sessenta, A geração de Betinho, São Paulo, Loyola, 1994. A AP, depois, na clandestinidade, perderia essas raízes e se tornaria um movimento marxista a mais, sem originalidade.

6 Emanuel de Kadt, Catholic radicals in Brazil, Oxford, Oxford University Press, 1970; Luiz Eduardo Wanderley, Educar para transformar; educação, Igreja Católica e política, Petrópolis, Vozes, 1984.

7 Para esse período, ver dados em Raimundo Caramuru de Barros, Brasil, uma Igreja em renovação, Petrópolis, Vozes, 1967.

8 Charles Antoine, L'intégrisme brésilien, Paris, Centre Lebret, 1973, p. 40.

9 Para ter em conta as diversidades, é interessante notar que foram publicados dois livros, no Chile e na Argentina, com o mesmo título e no mesmo ano, apresentando posicionamentos eclesiásticos opostos: Enrique Correa e José Antonio Viera-Gallo, Iglesia y dictadura, Santiago,Cesoc, 1986; Emilio F. Mignone, Iglesia y dictadura, Buenos Aires, E. del Pensamiento Nacional, 1986. Mas inclusive na Argentina um bispo, Mons. Angelelli, foi muito provavelmente assassinado pela ditadura militar.

10 Conferir a coleção Documentos da CNBB, com mais de sessenta volumes, publicada pelas Edições Paulinas, onde estão reunidas as inúmeras declarações dos bispos. $\mathrm{O}$ texto citado está no vol. $42, \mathrm{n}^{\circ} \mathbf{0}$.

11 Padre Júlio Maria, O catolicismo no Brasil, Rio de Janeiro, Agir, 1950. 
12 D. Paulo Evaristo Arns, Da esperança à utopia. Testemunho de uma vida, Rio de Janeiro, Sextante, 2001.

13 Nelson Piletti e Walter Praxedes, Dom Hélder Câmara. Entre o poder e a profecia, São Paulo, Ática, 1997.

14 Costa, Pandolfi e Serbin (orgs.), O bispo de Volta Redonda: memórias de D. Waldyr Calheiros, Rio de Janeiro, Fundação Getúlio Vargas, 2001. Ivo Poletto (org.), Uma vida a serviço da humanidade. Diálogo com D. Tomás Balduíno, São Paulo, Loyola/ Rede da Paz, 2004.

15 Documento "A doutrina da segurança nacional à luz da doutrina social da Igreja", em Luiz Gonzaga de Souza Lima, op. cit.

16 M. Regina do Santo Rosário, O Cardeal Leme, Rio de Janeiro, José Olympio, 1962, p. 180.

17 Entre os livros mais relevantes de Maritain: Primauté du Spirituel, Paris, Plon, 1927; Humanismo integral, São Paulo, Companhia Editora Nacional, 1937; Cristianismo e democracia, Agir, Rio de Janeiro, 1964; Os direitos do homem e a lei natural, Rio de Janeiro, Agir, 1967.

18 L. A. Gómez de Souza, A utopia surgindo no meio de nós, Rio de Janeiro, Mauad, 2003, cap. 19, "Mounier: na procura de um compromisso ético e exigente".

19 Emmanuel Mounier, Oeuvres, Paris, Seuil, 1961, especialmente, Feu la chretienté, no vol. III, texto de 1950.

20 Henrique C. de Lima Vaz, "Cristianismo e consciência histórica” I e II, "Cristianismo e história”, em Ontologia e história, São Paulo, Loyola, 2001. Ver L.A. Gómez de Souza, "Pe. Vaz: mestre de uma geração de cristãos", Síntese, vol. 18, n. 55, out.-dez. 1991.

21 Clodovis Boff; Frei Betto; Pedro Ribeiro de Oliveira; Rogério de Almeida Cunha; Luiz Eduardo Wanderley; Luiz Alberto Gómez de Souza; Herbert de Souza; Leonardo Boffe Domingos Barbé, Cristãos: como fazer política, Petrópolis, Vozes, 1987 (Col. Fazer).

22 L. A. Gómez de Souza, “As CEBs vão bem, obrigado”, Revista Eclesiástica Brasileira, fasc. 237, mar. 2000.

23 Ivo Lesbaupin; Lúcia Ribeiro; Solange Rodrigues dos Santos e Névio Fiorin, $O$ cotidiano das CEBs. Síntese de relatório de pesquisa, preliminar, Rio de Janeiro, Iser Assessoria, jan. 2004.

24 João Batista Libânio, "Inverno na Igreja. Anos 80", Tempo e Presença, ano 12, n. 249, jan.-fev. 1990.

25 Estação de seca na Igreja.Comunicações do ISER, ano 9, n. 39, 1990.

26 Peter Steingels, A People Adrift. The Crisis of the Roman Catholic Church in America, New York, Simon \& Schuster, 2003.

27 Pietro Prini, Lo scisma sommerso. Il messagio cristiano, la società moderna e la Chiesa cattolica, Roma, Garzanti, 1999.

28 Robert McClory, Rome et la contraception. Histoire secrète de l'encyclique Humanae Vitae, Paris, Les Éditions Ouvrières, 1998. 
29 Ver um livro de 1964, Thomas Roberts (org.), Contraception and holiness, New York, Herder and Herder.

30 Duas recentes pesquisas na Baixada Fluminense apontam nessa direção. Ver Lúcia Ribeiro e Solange Luçan, Entre (in)certezas e contradições. Práticas reprodutivas entre mulheres das comunidades eclesiais de base, Rio de Janeiro, Nau/Iser, 1995; Lúcia Ribeiro, Sexualidade e reprodução. O que os padres dizem e deixam de dizer, Petrópolis, Vozes, 2001.

31 Ceris, $O$ perfil do presbitero brasileiro, texto apresentado na 42 Assembléia Geral, CNBB, abr. 2004, Itaici, doc. 09/42 AG (SUB).

32 Rose Marie Muraro, Seis meses em que fui homem, Rio de Janeiro, Rosa dos Ventos, 1991. Ver também, Rosiska Darcy de Oliveira, Elogio da diferença. O feminino emergente, São Paulo, Brasiliense, 1991.

33 Leonardo Boff, Eclesiogênese, Petrópolis, Vozes, 1977, pp. 84-85. Ida Raming, "A posição de inferioridade da mulher segundo o direito canônico vigente", Concilium, Petrópolis, Vozes, n. 111, 1976/1.

34 Ver Cânon 129, parágrafo 2․ . Código do Direito Canônico, Loyola, São Paulo, 1987, p. 55. Diz o comentarista em nota da edição brasileira: "Reafirmando, em princípio, a capacidade dos que receberam o sacramento da ordem, para possuir e exercitar esse poder, deixa em aberta a porta para que os leigos possam cooperar em seu exercício. A gente se pergunta, se não há aqui o desejo de manter a velha legislação, pelo menos nas aparências. Se os leigos podem receber uma participação no poder de reger é porque têm uma base constitutiva para tanto no seu ser cristão. Por outro lado, advirta-se que essa possibilidade dos leigos não está restrita aos homens, mas se estende também às mulheres" (p. 55).

35 Danièle Hervieu-Léger, De la mission à la protestation. L'épolution des étudiants chrétiens, Paris, Cerf, 1973; L. A. Gómez de Souza, A JUC...,op. cit.

36 Publicada em Adista, Roma, n. 73, 16 out. 1999. A síntese publicada em L'Osservatore Romano de 23 de outubro ignora toda essa parte central da exposição.

37 Cardeal Paulo Evaristo Arns, bispos Tomás Balduíno, Luiz Cappio, Luís Gonzaga Fernandes, Jacinto F. de Brito, Moacyr Grechi, Francisco Austregésilo, Waldyr Calheiros, Pedro Casaldáliga, Adriano Ciocca, Aparecido Dias, Antonio Fragoso, Xavier Gilles de Maupeou, Erwin Kräutler, Emanuel Messias, Antonio Possamai, Diamantino Prata, Eugênio Rixen, Luiz Demétrio Valentini, Elias Manning, Franco Masserdotti, Mauro Morelli, José Maria Pires, Tiago Postma e Antonio Werlang.

38 José Maria Mayrink, "Bispos e fiéis pedem ao Papa o Vaticano 3”, O Estado de S. Paulo, 9 fev. 2003. Ver também Iniciativa internacional hacia un nuevo Concilio, 2002-2003, Balance y perspectivas, Madrid, www.proconcil.org

39 L. A. Gómez de Souza, Do Vaticano II a um novo concílio? Olhar de um cristão leigo sobre a Igreja, São Paulo, Loyola/Rede da Paz/Ceris, 2004. 
RESUMO - O AUTOR faz um balanço da Igreja Católica nas últimas décadas, fazendo notar diversidades e tensões internas e assinalando sua presença ativa na vida pública brasileira. Examina os vários momentos da relação entre a Igreja e a política. Numa avaliação do momento atual afirma, no sentido contrário de algumas análises, a relevância, ainda hoje, das pastorais sociais e das CEBs. Chama a atenção para uma crise da Igreja no momento presente, em relação a alguns temas que ela mantêm congelados, sobre a mulher, a sexualidade ou o celibato obrigatório dos clérigos. E finaliza com a proposta, atualmente em pauta, de começar o processo de preparação de um futuro concílio.

ABSTRACT - THE AUTHOR purviews the role of the Catholic Church over the last decades, bringing to light its diversities and internal tensions, and highlighting its active presence in Brazilian public life. He examines the various instances of the relationship between the church and politics. Assessing the present time, and going counter to certain analyses, he affirms that social pastoral initiatives and the Grassroots Ecclesiastical Communities are still relevant today. He calls our attention to the ongoing crisis of the Church regarding certain issues that remain "frozen": women, sexuality, and the compulsory celibacy of the clergy. And he ends with the proposal, currently being discussed, to begin preparations for a future council.

Luiz Alberto Gómez de Souza é sociólogo, diretor executivo do Centro de Estatística Religiosa e Investigações Sociais (Ceris), assessor de movimentos e pastorais sociais, antigo dirigente da Ação Católica e professor em universidades do Rio de Janeiro.

Texto recebido e aceito para publicação em 4 de outubro de 2004.

Estudos AvanÇADOS 18 (52), 2004 